\title{
Retaining Professional nURSes in South Africa: NURSE MANAGERS' PERSPECTIVES
}

\section{Authors:}

Elizabeth Mokoka ${ }^{1}$

Martha J. Oosthuizen ${ }^{1}$

Valerie J. Ehlers ${ }^{1}$

\author{
Affiliations: \\ ${ }^{1}$ Department of Health \\ Studies, University of \\ South Africa, South Africa
}

Correspondence to:

Martha Oosthuizen

email:

oosthmj@unisa.ac.za

\section{Postal address:}

University of South Africa,

Department of Health

Studies, PO Box 392,

UNISA 0003, South Africa

\section{Keywords:}

baby boomers; generation

$X$; generation $Y$; nurse

retention; silent generation

Dates:

Received: 04 Aug. 2009

Accepted: 26 July 2010

Published: 03 Nov. 2010

How to cite this article: Mokoka, E., Oosthuizen, M.J., Ehlers, V.J., 2010,

'Retaining professional nurses in South Africa: Nurse managers'

perspectives', Health $S A$ Gesondheid 15(1), Art. \#484, 9 pages. DOI: $10.4102 /$ hsag.v15i1.484

This article is available at:

http:/ / www.hsag.co.za

C 2010. The Authors. Licensee: OpenJournals Publishing. This work is licensed under the Creative Commons Attribution License.

\section{ABSTRACT}

South Africa is experiencing a serious shortage of nurses, which has to be addressed to prevent crises in health care services. Previous studies (Fletcher 2001:324; Oosthuizen 2005:117) found that nurses change their work environment due to dissatisfaction with their job situations. This implies that creating a favourable environment in the workplace situation could help retain professional nurses in their posts, implying that retention strategies should be effective.

An exploratory, descriptive, contextual and qualitative design was used to describe nurse managers' views on factors which could influence professional nurse retention, as well as their views regarding attributes that were required to enable them to contribute towards enhancing professional nurse retention. A purposive sample of nurse managers employed in public and private hospitals in the Gauteng province was selected. Semi-structured interviews were conducted with 21 nurse managers. The results were analysed qualitatively and contextualised within Vogt, Cox, Velthouse and Thames's Cork-Top (Bottleneck) Theory of Nurse Retention (1983) and Lewin's Force-Field Analysis Theory (1952).

Factors pertaining to individual nurses, the organisation and nurse managers could influence the retention of professional nurses. Poor working conditions, long and inconvenient working hours, uncompetitive salaries and professional development of nurses have to be addressed to enhance professional nurses' retention. Unsafe working environments and a lack of resources threaten the safety and well-being of nurses and patients and contribute to high turnover rates. Nurse managers have to address shortcomings in their managerial and leadership skills and implement changes within a multigenerational nursing workforce and challenging working environments.

\section{OPSOMMING}

Suid-Afrika ervaar 'n ernstige tekort aan verpleegkundiges wat aangespreek moet word ten einde krisisse in gesondheidsorgdienste te voorkom. Vorige studies (Fletcher 2001:324; Oosthuizen 2005:117) het bevind dat verpleegkundiges hulle werksomgewing verander as gevolg van ontevredenheid met hulle werksituasies. Dit impliseer dat die daarstelling van' $n$ gunstige omgewing in die werkpleksituasie, kan help om professionele verpleegkundiges in hulle poste te behou, wat beteken dat retensiestrategieë doeltreffend moet wees.

'n Verkennende, beskrywende, kontekstuele, kwalitatiewe ontwerp was gebruik om verpleegbestuurders se sienings te bekom, oor faktore wat professionele verpleegkundiges se retensie kan beïnvloed, asook hulle sienings omtrent vereiste hoedanighede wat hulle in staat sou stel om professionele verpleegkundiges se retensie te bevorder. ' $n$ Doelgerigte steekproef van verpleegbestuurders in openbare en private hospitale in die Gauteng provinsie is gekies. Semigestruktureerde onderhoude is met 21 verpleegbestuurders gevoer. Die resultate is kwalitatief ontleed en gekontekstualiseer volgens Vogt, Cox, Velthouse en Thames se Kurkprop Bottelnek (Cork-Top Bottleneck) Teorie van Verpleegretensie (1983) en Lewin se Kragveld Analise Teorie (1952).

Faktore met betrekking tot individuele verpleegkundiges, die organisasie en verpleegbestuurders kan die retensie van professionele verpleegkundiges beïnvloed. Swak werksomstandighede, lang en ongerieflike werksure, nie-mededingende salarisse en professionele ontwikkeling van verpleegkundiges moet aangespreek word om professionele verpleegkundiges se retensie te bevorder. Onveilige werksomgewings en 'n gebrek aan hulpbronne bedreig die veiligheid en die welsyn van verpleegkundiges en pasiënte en dra by tot hoë omsetsyfers. Verpleegbestuurders moet die tekortkominge in hulle bestuurs- en leierskapsvaardighede aanspreek en veranderinge implementeer binne ' $n$ multigenerasie verpleegwerkkrag en uitdagende werksomgewings.

\section{INTRODUCTION}

Nurse turnover rates in South Africa influence the country's nursing shortages. This phenomenon appears to occur globally (Barney 2002:154). Internal migration within the South African health care sector and emigration to other countries are two major factors contributing to the high turnover rate of South African professional nurses. South African nurses are lured by more affluent countries that have more to offer in terms of competitive incentives, better working conditions and resources, safety, and a lower prevalence of HIV / AIDS. Professional nurses who discontinue practising as nurses and prefer non-nursing jobs which offer better salaries, more job satisfaction and better working hours (Ehlers 2003:81) further aggravate the problem. During 2008, an average of $40.3 \%$ of professional nurses' posts were vacant throughout South Africa (Health Systems Trust 2008). The provinces with the highest percentages of vacancies were the Eastern Cape (53.6\%), the Free State (51.6\%), Limpopo (43.7\%), Kwa-Zulu Natal (39.6\%) and Gauteng (34.4\%). These percentages of vacant professional nurses' posts indicate a dire necessity to retain the currently professionally active nurses. 
Statistics from the South African Nursing Council (SANC 2005) indicate that there was a decline of nearly $42 \%$, from 1996 to 2005, in the number of nurses who completed the 4-year programme from training institutions, including universities, from all nine provinces of South Africa. Simultaneously, the South African population between 1996 and 2006 had grown by $14.36 \%$ from 40 583573 to 47390900 (Statistics South Africa 2006). The average ratio of professional nurses to population was 1:471 during 2006, with marked differences between the provinces.

The high cost that comes with turnover has highlighted the need for organisations to make retention of staff their numberone priority. According to Maxwell (2004:316), retention entails preventing people from leaving an organisation to work elsewhere. This is not an easy task. It requires organisations and management to give attention to the employee market and to understand what people are seeking from the work environment in order to retain them. Organisations will need to identify the reasons why employees leave, and address them. These reasons will most likely differ from one organisation to the next and will be influenced by individual and group characteristics, the culture of the organisation and the nature of that organisation's core business (Maxwell 2004:1). A literature review showed that better remuneration, better living and working conditions, lack of facilities or resources, lack of promotion, heavy workloads and unsafe working and living environments contribute to nurses' decisions to leave South Africa (Oosthuizen 2005:117; Xaba \& Phillips 2001:6).

The current nursing workforce comprises four generations, (1) the silent generation, (2) baby boomers, (3) generation $X$ and (4) generation $\mathrm{Y}$, or millennials. While diversity in the workplace stemmed from culture, race or gender, the difference in generations adds another dimension to an already complex work environment. Age is not the only character that differentiates generations. Other elements such as historical events during the years of birth, political, economic and global changes impact on the people born during specific times. These aspects influence the upbringing, value systems, fashion trends, lifestyle and eventually work ethic and workplace behaviour, habits, needs, expectations and aspirations of a generation (Duchscher \& Cowin 2004:494; Hammill 2005:2; Jooste 2003a:142; Moore 2002:1; Rhule 2004:52; Sherman 2006:3). It is therefore imperative that managers and organisations address these differences when developing or implementing retention strategies.

In the health care industry, the challenge to retain professional nurses is ongoing because of the global nursing shortage and factors that are related to the health care environment; these include working hours, increased workload, poor salaries and working conditions, which make retention efforts more challenging than in other industries. Health authorities are faced with a challenge to come up with strategies, policies and legislation that will direct the recruitment and retention of nurses (Kaestner 2005:8). Previous studies have identified factors relating to the individual nurse (monetary and nonmonetary rewards), the manager or supervisor (enhancing nurses' satisfaction levels), and the organisation (positive work environment), as being crucial in enhancing nurse retention (American Nurses' Association 2001:2; Bethune, Sherrod \& Youngblood 2005:25; Cameron \& Armstrong-Stassen 2005:1; Force 2005:340; Hall 2004:31; Pullan \& Lorbergs 2001:24; Strachota et al. 2003:113; Wilson 2005:135).

\section{PROBLEM STATEMENT}

The high turnover rates amongst South African nurses, coupled with the decreasing numbers of nursing recruits, pose a threat to health care delivery. A global nursing shortage, continued recruitment of South African nurses to work in foreign countries and a decrease in the number of nurses who complete their training imply that health care services compete in recruiting nurses and in retaining nurses in their organisations. The current multigenerational nursing workforce, which comprises four different generations, (1) the silent generation, (2) baby boomers, (3) generation $\mathrm{X}$ and (4) generation $\mathrm{Y}$, displays diversity in characteristics, values, needs, attitudes and work ethic. It is therefore critical that retention strategies are tailored to accommodate these different needs for each specific generation. This will not only enhance stability and retention of the multigenerational workforce, but will also enhance patient care. The research problem pertains to how nurse managers and organisations can enhance nurse retention rates.

\section{PURPOSE, OBJECTIVES AND RESEARCH QUESTION}

The purpose of the study was to explore nurse managers' views about factors within the workplace that may affect nurses' retention. The objectives of the study attempted to:

- Identify nurse managers' views about factors affecting nurses' retention rates.

- Describe actions which organisations could take to create a workplace environment that would promote the retention of professional nurses of different generations.

The research question arose as to what actions organisations could take to create a work environment and working conditions that will enhance the retention of professional nurses from all generations.

\section{Theoretical framework of the study}

Two theories formed a basis for contextualising the phenomenon of nurse retention:

- Vogt, Cox, Velthouse and Thames's Cork-Top (Bottleneck) Theory of Nurse Retention.

- Lewin's Force-Field Analysis Theory.

Vogt,Cox, Velthouseand Thames's Cork-Top(Bottleneck) Theory of Nurse Retention (1983:130) builds on Maslow's Hierarchy of Needs Theory, but goes a step further by addressing areas where the flow of human needs might be blocked or inhibited, with a special emphasis on nursing. Maslow looks at human needs and motivation. These needs are divided into five levels in a hierarchy, in order of priority (1) physiological, (2) safety, (3) social, (4) esteem and (5) self-actualisation needs (Booyens 1998:458; Furnham 1997:250; Gurney 1990:23). Vogt et al.'s (1983) theory is one of nurse retention and not motivation. The shape of the champagne bottle cork is used to illustrate the theory: where the cork is narrow, it signifies areas of constrictions or limitations in fulfilling human needs, while wider areas indicate expanded opportunities. According to this theory, retention of nurses is affected by the availability or unavailability of means to meet needs. A bottleneck signifies a stage or place where progress is blocked or impeded in fulfilling needs or in attaining gratification.

Lewin's model of change identifies driving and restraining forces, which might require change to bring about balance or an ideal climate in the workplace. Driving forces are seen as motivating and positive in nature, while restraining forces are regarded as negative (Schwering 2003:362). The theory further describes the steps that need to be followed to implement change. In order to effect change, driving and restraining forces need to be identified and their respective strengths assessed. Once assessed, balance must be shifted towards the direction of change and requires a process occurring in three steps (1) unfreezing, (2) moving and (3) refreezing (Sullivan \& Decker 2001:219; Tappen 2001:209).

\section{RESEARCH METHOD AND DESIGN}

An exploratory, descriptive, contextual, and qualitative design was used to determine, explore and describe nurse managers' views on factors which could influence professional nurse retention, as well as their views regarding attributes that were required to enable them to contribute towards enhancing professional nurse retention. 
TABLE 1

Employment duration of participating nurse managers

\begin{tabular}{llll}
\hline Number of years in position & Participant: Private sector & Participant: Public sector & Total \\
\hline $0-5$ years & 2 & 3 & 5 \\
$6-11$ years & 5 & 4 & 9 \\
$12-15$ years & 1 & 2 & 3 \\
16 or more years & 1 & 3 & 4 \\
\hline Total & $\boldsymbol{n}=\mathbf{9 ( 4 3 \% )}$ & $\boldsymbol{n = 1 2 ( 5 7 \% )}$ & $\boldsymbol{n}=\mathbf{2 1}(\mathbf{1 0 0} \%)$ \\
\hline
\end{tabular}

\section{Population and sample}

The population in this study included a purposive sample of nurse managers employed in public and private hospitals in the Gauteng province, South Africa. Participants had to be employed full time as nurse managers, and had to take responsibility for staff-related human resource management functions such as recruitment, selection, orientation, induction, retention and turnover of professional nurses. Nurse managers of both sexes were eligible for inclusion, but only female nurse managers participated.

\section{Selection of participants and collection of data}

Existing literature suggested various ways of selecting participants for semi-structured interviews, especially the number of participants (De Vos et al. 2005:294).

Two criteria, sufficiency and saturation of data, are identified. Sufficiency refers to the number of participants, which should be enough to reflect the range of participants that make up the population, so that their experiences can be generalised to those outside the sample. Saturation refers to a point in the study at which the researcher does not gain any new knowledge about the phenomenon under study (De Vos et al. 2005:294). In this study, data saturation was reached after 18 interviews were conducted. Three more interviews confirmed that data saturation had indeed been reached, resulting in a total of 21 nurse managers interviewed.

The interview schedule comprised eight open-ended questions. These related to the objectives of the study, which were the factors influencing professional nurse retention, as well as the attributes that are required to enable nurse managers to enhance professional nurse retention in their organisations. Some closedended questions were asked to determine a biographic profile of the participants. After approval of the interview schedule by the promoters of the study and two nurse researchers experienced in qualitative research methods, it was pre-tested with four nurse managers who met the selection criteria set, but who did not form part of the selected sample.

The one-to-one, semi-structured interviews were conducted with nurse managers who were responsible for human resource management involving nurses in their organisations. All the interviews were conducted by the researcher, who took field notes and operated the audiotape recorder, in order to maintain confidentiality. An atmosphere conducive to interviewing was provided and interviews were audiotaped and later transcribed verbatim.

\section{Data analysis}

The data obtained during the semi-structured interviews with the nurse managers was analysed according to the steps proposed by Marshall and Rossman (1995:115) and Creswell (2003:191).

TABLE 2

Classification of managers according to generation

\begin{tabular}{ll}
\hline Generation according to year of birth & Number of managers \\
\hline Silent generation (from 1922 to 1942) & $2(9.5 \%)$ \\
Baby boomer (from 1943 to 1960) & $14(66.7 \%)$ \\
Generation X (from 1961 to 1981) & $5(23.8 \%)$ \\
Generation Y (from 1981 to 2000) & 0 \\
\hline Total & $\boldsymbol{n = 2 1 ( 1 0 0 \% )}$ \\
\hline
\end{tabular}

These steps entailed organising and preparing data for analysis, reading and rereading through data to obtain a general sense of the information and its overall meaning, and then to commence coding of data according to themes and categories. This was done initially in the concrete language of the respondent and then clustered into categories, with their concrete meaning being transformed into the language of the concepts.

\section{RESULTS}

\section{Biographical profile of participants}

Table 1 gives an indication of participants' experience in terms of years in the position as manager in their organisation.

Of the 21 nurse managers who comprised the sample for this study, 12 were from the public sector and 9 were from the private sector; $76.2 \%(n=16)$ had occupied their positions for longer than 5 years, and could therefore provide information about factors influencing professional nurses' retention rates. This implied that only $5(23.8 \%)$ nurse managers had fewer than 5 years' experience. Table 2 displays the ages of participants organised according to the different generations. No participants were in the age group that is classified as Generation Y.

A managerial position requires experience and specific qualifications. Generation $Y$ nurses were in their twenties and therefore not expected to be managers. Employees from different generations display different characteristics, values, needs, attitudes and work ethic. Generation $X$ and $Y$ employees might display different attitudes towards their jobs and careers than managers from the silent generation and baby boomers (Neuhauser 2002:470; Rhule 2004:40).

Of the $21(100 \%)$ nurse managers who participated, $15(71.4 \%)$ had qualifications in human resources management, while $6(28.6 \%)$ indicated that they did not have any formal qualifications, but had received in-service education and training related to human resource functions.

\section{Institutional policies}

All 9 (43.0\%) nurse managers from the private sector affirmed that their organisations had policies for professional nurse retention. Of the $12(57.0 \%)$ nurse managers from the public sector, $4(19.0 \%)$ were unsure whether such a policy existed, while the other $8(38.1 \%)$ said they did not have such a strategy. Fifteen $(71.4 \%)$ of the participants mentioned that there were opportunities where nurse retention was discussed, while 4 $(19.0 \%)$ mentioned that it was not formally discussed, but 'talked about' on an informal basis. Only $13(61.9 \%)$ nurse managers conducted exit interviews when nurses left their institutions. Five $(23.8 \%)$ participants mentioned that they conducted exit interviews with some nurses who resigned, while $3(14.3 \%)$ indicated that they did not do so. One of the participants who did not conduct exit interviews reported: 'They never tell you the truth, anyway, so it is a waste of time and energy.'

\section{Factors that may influence the retention of nurses}

Data analysis of information collected from nurse managers on retention and related factors revealed three major themes and a number of categories supporting these themes. A summary of the themes and categories is presented in Table 3. 
TABLE 3

Themes and categories of factors influencing the retention of professional nurse

\begin{tabular}{|c|c|}
\hline Theme & Category \\
\hline Theme 1: General factors that can influence professional nurse retention & $\begin{array}{ll} & \text { Working conditions } \\
\dot{\cdot} & \text { Scheduling of working hours } \\
\cdot & \text { Professional development } \\
\cdot & \text { Rewards and benefits } \\
\cdot & \text { Relationships at work } \\
\text { : } & \text { Re-attracting retired nurses } \\
\text { - Image of nursing } \\
\quad \text { Impact of values }\end{array}$ \\
\hline Theme 2: Organisational factors that could influence professional nurse retention & $\begin{array}{ll}\text { - } & \text { Safety in the workplace } \\
\text { - } & \text { Lack of resources. } \\
\text { - Organisational policy and strategic planning } & \text { Organisational culture and change }\end{array}$ \\
\hline Theme 3: Nurse manager's role in enhancing professional nurse retention & $\begin{array}{ll}\cdot & \text { Empowering nurse managers } \\
\dot{\cdot} & \text { Training and development } \\
\text { : } & \text { Leadership role } \\
\text { - } & \text { Management skills } \\
& \text { Managerial attributes role in retention of a multigenerational workforce }\end{array}$ \\
\hline
\end{tabular}

\section{Theme 1: General factors that can influence professional nurse retention}

The general factors that influenced nurse retention rates according to the nurse managers, included (1) working conditions and hours, (2) professional development opportunities, (3) rewards and (4) relationships at work.

\section{Working conditions}

Conditions in the workplace influence professional nurses' intentions to leave their organisations. Nursing shortages with resultant heavy workloads, excessive mandatory overtime, the unsatisfactory physical state of hospitals (without basic resources and equipment) and demands by management, authorities, patients and visitors made it almost impossible for nurses to function effectively, prompting their decisions to leave their employer. This was evident in the following nurse managers' statements:

'Hospitals have deteriorated. This is really not good for patients and the nurses themselves.'

'Working conditions are difficult. With so many patients, some of them very, very ill, nurses feel they are not really giving good quality care. They are despondent and therefore some feel they'd rather leave.'

El-Jardali et al. (2007:9) identify the importance of working conditions as a push-or-pull factor influencing health workers' retention rates. Oosthuizen (2005:117) found that nurses who left South Africa to work in foreign countries cited poor working conditions and heavy workloads as their major reasons for leaving their employers.

\section{Scheduling of working hours}

Work schedules, inflexible hours, long shifts and mandatory overtime cause disillusionment, influencing nurses to look for other jobs. Older nurses were reportedly feeling the strain of long hours, forcing them to retire earlier than they had intended to. Younger nurses were reportedly unhappy with shifts as these impacted negatively on their family and social lives. While nurse managers empathised with nurses, they declared feelings of helplessness to change these conditions by stating:

'Die ure is lank. Dis veral moeilik in jou besige plekke soos teater en intensief.' (The hours are long. It is especially difficult in your busy places like theatre and intensive).

'Young and old, all nurses feel the strain with straight shifts.'

Staff shortages hamper in-service education and on-thejob training of nurses, especially orientation and induction programmes for newly appointed and newly qualified nurses. The following statements support these standpoints:

'... Partykeer moet' $n$ mens aan die diep kant gegooi word, sonder oriëntasie of induksie. Daar is net nie genoeg hande nie.' (... Sometimes a person must be thrown in at the deep end, without orientation or induction. There are simply not enough hands).
'Training is lacking, especially for the newly qualified nurses, who are not experienced. They do not feel safe, especially with conditions they have never dealt with ...'

\section{Professional development}

In order to give quality care, nurses need development and empowerment. According to Butler (2000:5), the best places to work are places where nurses are provided with training and opportunities to develop. Improving professional practice and enhancing nurses' clinical competence through ongoing education may increase retention and job satisfaction and help ensure a stable workforce.

\section{Rewards and benefits}

Nurse managers identified the importance of monetary and non-monetary rewards in order to increase retention. Monetary rewards were mainly competitive salaries, performance bonuses and scarce skills remunerations. Non-monetary rewards included extended leave, promotions and creating facilities for child care and recreation. Participants viewed salary as the primary source of job dissatisfaction amongst professional nurses, and also did not think that messages of encouragement and congratulatory notes recognising good performance would make any difference to motivate nurses, contrary to what Pullan and Lorbergs (2001:21) maintain. Statements made regarding these factors were:

'... getting remuneration on par with other professions like law, architecture and IT will surely encourage our nurses to stay.'

'Promotion and salary structure must be reviewed. Except that the pay is dreadful, these poor nurses really work hard and selflessly give their everything. Their salaries have got to improve in order to keep them.

South African nurses, working in foreign countries, cited financial reasons as key factors that influenced their decisions to leave South Africa (Oosthuizen 2005:117).

\section{Relationships at work}

Participants noted that relationships in the workplace could influence nurses' decision to stay or leave, including friendship and support between colleagues and peers. Negative relationships are characterised by verbal abuse and a lack of respect from doctors, nursing colleagues and nurse managers. At times, nurses are abused verbally and even physically by patients and their families. Where relationships with colleagues were happy and collegial, nurse managers agreed that patients also received good care, while nurses who helped one another made the workload more bearable, contributing to lower turnover rates in such units. Comments that attested to this were:

'... no respect from the public, families of patients and coworkers.'

'Verbal abuse from doctors and some managers must also be stopped, so that nurses remain in their jobs.' 
According to Meyer, Naude and Van Niekerk (cited in Naude \& McCabe 2005:4), support in the workplace develops when positive relationships are built, where there is mutual respect, trust and integrity. The work environment needs to be friendly and supportive and the workplace must have a welcoming atmosphere. According to Upenieks (2003:573), nurses want to be appreciated and respected by management and doctors. They want their expertise to be recognised and to participate in decision-making processes pertaining to patient care.

\section{Re-attracting retired nurses}

Responses from participants were mixed regarding the effective use of retired nurses to alleviate nursing shortages, with some nurse managers being in favour of their return, while others felt they were not as productive as they would like them to be. While nurse managers mostly agreed that these nurses had vast amounts of experience, the important issue was whether they could apply that experience as effectively as they used to, whether that experience would still be relevant and current and if they would be able to transfer that experience to newly qualified, inexperienced nurses. These different opinions are illustrated in the following observations:

'Daar is heelwat personeel wat nog kan werk vir 'n paar jaar. Gee hulle erkenning vir hulle kundigheid; maak seker dat daar steeds genoegsame bevorderingsmoontlikhede geskep word.'

[There are still a number of staff that can work for a few more years. Give them recognition for their knowledge; ensure that enough opportunities for their promotion are created].

'They have enough experience. Bring them back and relieve the shortage.'

Statements by nurse managers who were against bringing back retired nurses included:

'They are out of touch with what is happening now. They won't cope.

While there were differences of opinion, participants agreed that retirees could play a role. They offered various alternatives for changes that could be made in the workplace to accommodate the retired nurses who were returning to practice, including the following suggestions:

'Schedule their working hours so that they have breaks in between: 12-hour shifts are too long.'

'Giving them lighter duties and mainly using their skills in mentoring will alleviate the shortage.

Williams et al. (2006:205) reported that inactive nurses in the USA would consider returning to the nursing profession if they could find a flexible work environment and attend refresher courses.

\section{Impact of values}

Values were attached to how nurses viewed their positions, responsibilities and commitment to an organisation. Participants reported a distinct difference between older and younger nurses in terms of their beliefs. The older nurses emphasised rank, age and job responsibilities like being in charge of a unit, while the younger nurses were more interested in getting the job done within the shortest time possible, disregarding rank and seeking permission from older, senior, more experienced nurses. This, according to the nurse managers, had the potential for conflict as each group felt strongly about their beliefs. Participants maintained that older nurses were more caring, patient and took time to talk to patients, while the younger nurses would perform their tasks in a professional way, but quickly move on to the next patient or task. Participants concurred that both approaches had advantages. Older nurses brought the human touch, while the younger nurses completed tasks expeditiously. Some of the responses that attest to these standpoints are:

'The older nurses see nursing as a calling and follow the traditions of the old school. The young ones are really productive and complete tasks.'
'The old guard take their time, but the young ones are quick and finish their tasks, because they are more task-directed, while the older ones are more person-directed.'

According to Gopwani (2004:2) older generations are needed to orientate, induct, mentor and teach new recruits. Accommodating the four generations with different values and diverse needs within the work environment poses many challenges.

\section{Image of nursing}

Participants maintain that the image of nursing needs to be improved, in order to improve nurse retention. The following statements illustrate these participants' views:

'I don't think anyone of us will want their child to be a nurse. Except that people do not respect you, it is too much sacrifice for nothing.'

'We must make the media and the people at large change their mind about us. It is up to us.

\section{Theme 2: Organisational factors that could influence professional nurse retention}

Organisational factors, potentially influencing the professional nurse retention rate, include safety in the workplace, availability of resources, organisational culture and changes.

\section{Safety in the workplace}

There was consensus that factors relating to the organisation influenced the retention of nurses. Participants expressed concerns about the physical safety of nurses in their workplaces. Lack of safety in both the working environment and en route to and from work was cited as one of the main factors that affected retention. Hospital security was reportedly not vigilant, with incidents of violence being perpetrated in front of security. Nurses' personal possessions were not safe, with instances of possessions and valuables being stolen at nurses' stations, duty rooms and even from inside nurses' lockers. The following observations illustrate the finding:

'Hospitals are not safe. Nurses are in constant fear of being attacked on duty and on their way home. Most of them do not have cars.'

'Make hospitals safe by hiring private security firms and put strong control at all gates and entrances.'

Runy (2006:2) postulates that in order to improve the retention of staff, organisations need to develop and maintain safe work places, and also emphasises that safety is compromised by neglected and poorly maintained buildings, and non-functioning equipment.

\section{Lack of resources}

A shortage of supplies and sometimes dysfunctional or lacking equipment were decried by nurse managers as key issues that organisations should address to enhance nurses' retention. Refurbished and better-equipped hospitals will enhance quality care to patients and nurses' levels of job satisfaction, affecting nurses' retention levels positively. The following responses support these points:

'Replace old, dysfunctional equipment. They make patient care very dangerous and nurses do not feel safe using facilities/equipment. Lack of medicines and other stock also makes nursing unsafe.'

'Lack of protective clothing also compromises the safety of nurses in the case of highly infective conditions.'

The overall feeling amongst nurse managers was that organisations had insufficient and ineffective human resource management policies. Some organisations did not have policies on recruitment, retention or performance approval. Nurse managers felt that career development is one of the crucial aspects influencing nurses' decisions to remain in a specific organisation. This was reportedly one of the most cited reasons during exit interviews. The following statements indicate what nurse managers had to say about policies: 
'Health policy as it is did very little to address the nursing shortage and exodus, and even worse, it does not affect some organisations.'

'We need a plan to strengthen our organisations. We need a directing policy, but each organisation or group must have their own plan.'

It is the responsibility of hospital managements to ensure that nurses have the resources to enable them to practice in a safe and efficient way. General unacceptable conditions in hospitals and a shortage of personnel put patients and nurses at risk and influence turnover rates (Oosthuizen 2005:209).

\section{Organisational culture and change}

Statements related to organisational culture emerged repeatedly as a factor that must be taken into consideration when organisational change is being considered. Participants felt that organisations have to change to retain nurses, especially the newly qualified, young nurses who have different mindsets from the older generations. One participant attested to this:

'Maybe the traditions of nursing and how we do things are the problem. Young nurses are not used to them.

The culture of the organisation can simply be interpreted as the way things are done in an organisation. Participants contemplated that the best step to address problems related to retention and recruitment would be to introduce change by redesigning health care delivery and health care organisations. They agreed that managing this change would prove challenging, and a statement to this effect was:

'We need to change certain things if we do not want health care to be in a crisis. Maybe it is already.

Booyens (1998:479) maintains that effective organisations require advanced planning and structuring of any changes and appropriate leadership styles.

\section{Theme 3: Nurse managers' roles in enhancing professional nurse retention}

Nurse managers could contribute towards enhanced retention rates of professional nurses by fulfilling their roles pertaining to empowerment, training or development, leadership and management.

\section{Empowering nurse managers}

Nurse managers reportedly had little autonomy to fulfil their management roles during challenging times. Despite agreeing that they had powers to perform certain functions independently, they perceived their position as lacking authority and were expected to consult executives, hospital managers or the regional offices before they could act on matters which they could actually handle themselves. Lack of or limited communication between the authorities, peers and doctors limits their ability to contribute meaningfully when issues relating to nurse retention are discussed. Decisions involving nurses and nursing were taken by authorities without a health care or nursing background. This impacted negatively on nurse managers' motivation levels and rendered them unable to motivate nurses in turn. This is corroborated by the following utterances:

'Matrons are at times helpless. We are not allowed by policy to make certain decisions. We still have to wait for permission.

'Doctors do not communicate their frustration with nurses to us.

They resort to shouting and being abusive. By the time you hear about it, the relationship is damaged.

According to Jooste (2003a:233), empowered managers feel vital to the health care organisation's successes, and empowerment can be regarded as a vote of confidence in the manager's ability to contribute positively towards the success of the organisation.

\section{Training and development}

Although the majority of participants in this study had training in human resource management, there were concerns about areas of management where some felt they lacked skills. The overall feeling was that in-service training was insufficient to provide management skills required in the current health care environment, and that the content of nurse management programmes and in-service training might be outdated and irrelevant. Lack of knowledge on labour issues, financial and conflict management were expressed:

'We have a qualification, but health care changes, our role changes. We are expected to draw budgets. In my time, nursing administration courses did not teach us about money. Nurses never talked money.'

'We need to be taught how to deal with labour issues without depending on the human resource department.'

The changing health care industry has put remarkable pressure on the nurse manager. Shaffer (2003:1) sees the nurse manager as vital in effecting nurse retention and subsequently the success of any health care organisation, and if organisations want to keep nurses, it is essential that they train excellent nurse managers.

\section{Leadership role}

The general feeling amongst participating nurse managers was that not much was being done in their organisations to recognise or even develop their leadership roles. The interviewees agreed that the health care environment requires managers who are also leaders. This was expressed in the following comments:

'We did management courses, but leadership is something else. How do we achieve it?'

'If I could influence nurses to stay, then I will call myself a good leader.'

Current nursing literature has shifted focus from talking about management, and moved towards increased talk of leadership (Donnelly 2003:2; Jooste 2003b:25; Sellgren, Ekvall \& Tomson 2006:349). The essence of leadership is the ability to exert influence over other people (Tappen, Weiss \& Whitehead 2004:5).

\section{Management skills}

Skills in management were seen in the context of taking charge of the current workplace, where four different generations were working together. This is further complicated by factors that pose challenges in health care delivery, (1) the escalating shortage of nurses, (2) very ill patients that require more intensive care, (3) poor working conditions, (4) lack of resources and equipment and (5) a dwindling supply of new recruits. The situation, according to nurse managers, requires exceptional management skills that require continual updating, in order to manage challenges as they occur. This was observed by nurse managers as follows:

'Management today is not what it was in the past. There are more demands and different demands too.'

'Nurses of today have a different approach or understanding of nursing. Their needs come before the needs of patients. Then you get the old ones who are tired but put patients first. You need to know how to manage that.'

Jooste (2003b:20) maintains that an effective nurse manager should be a planner, organiser, human resource officer, director and controller.

\section{Managerial attributes}

According to Fitzpatrick (2003:90), the art of managing people requires the manager to have exceptional people skills and connect with subordinates on a human level. This entails understanding their needs, fears, hope and dreams. According to Jordan-Evans and Kaye (in Rhule 2004:76), managers exert great influence over the people they manage and have a role to play in employees' decisions to leave or remain in an organisation. However, the statement posed in one question in the interview schedule, that 'people do not leave their jobs, they leave their managers' was perceived negatively by some of the nurse 
managers participating in this study. They felt the researcher was accusing them of being responsible for nurses leaving their organisations. Showing the managers literature which supported this statement convinced them that other authors were in agreement with this. However, one nurse manager in this study agreed that some nurses could indeed be leaving because of their managers. Some nurse managers responded as follows:

'I agree that we play a crucial role in nurse retention, but we do not control all the factors that cause nurses to leave.'

'Dit is tot ' $n$ mate waar. As die bestuurder die personeel hanteer met die nodige respek, ondersteuning, erkenning, ensovoorts, sal die personeel nie sommer van werk verander nie.

[It is true to some extent. If the manager treats staff with the necessary respect, support, recognition, etcetera, staff will not easily change jobs].

Schoealer (in Rosebrough 1999:2) supports the notion that nurses do not leave their jobs, but leave bad managers. The solution Schoealer offers for solving this problem is to provide extensive managerial and leadership training to managers, supervisors and nurse executives.

The nurse managers who participated in this study were committed to enhancing the quality of patient care. There was a realisation that this could be achieved by making the workplace attractive and a place where nurses wanted to continue working. Supporting statements to that effect include the following:

'Our health care must change. We must make our hospitals places of excellence, where patients get better and nurses want to work.'

'In the private sector, there are continued programmes to improve working conditions and working environments. That is why nurses go from public to private because private hospitals continue to get better. They have resources.'

Despite nursing shortages, increased workloads and poor conditions in hospitals, there is evidence that some hospitals, specifically in developed countries, are successful in their recruitment and retention of nurses (Aiken, Smith \& Clarke 1994:772; Bliss-Holtz, Winter \& Scherer 2004:38; Cook, Hiroz \& Mildow 2006:2).

\section{Manager's role in retention of a multigenerational workforce}

Managing a multigenerational workforce posed certain challenges. While some managers were not familiar with the terms used to distinguish the four generations in the workplace, participants mentioned differences in terms of work behaviours, attitudes towards work and superiors, experiences, work attendance and communication aspects. The following comments illustrate this notion:

'The older nurses are slow but very thorough and experienced. The younger nurses are alive and these are the ones who easily find work here and abroad; we must keep them.'

'The young nurses must be guided. We must bring back professionalism. Some of them don't know why they came to nursing. They do not care.'
'Generations $X$ and $Y$ are characterised by absenteeism, single parenthood, HIV/Aids-infected and-affected. The very young ones are also not "hands on". During training, they spend most of their time as observers. They still need experience.'

'Baby boomers is oor die algemeen meer professioneel as generasie $X$ en $Y$, dus moet daar baie meer klem gelê word op die jonges om respek aan te leer en te betoon, betroubaar te wees, maar ook dat die partye mekaar moet verdra en met mekaar kommunikeer en ook om van mekaar te leer.' (Baby boomers are generally more professional than generation $X$ and $Y$, therefore there must be pressure on the young ones to learn and show respect, be trustworthy, but also that the parties must tolerate one another, communicate and learn from each other).

In a study by Moats-Kennedy (in Hart 2006:11) about motivating cross-generation co-operation, the author suggests varying the reward system by generation and giving each generation what it wants: More money to the baby boomers and more time off for the two younger generations. Stuenkel, Cohen and De la Cuesta (2005:283) regard awareness of differences amongst generations as a first step towards retention. This will lead the nurse managers to tailor their management styles to an individual's generation background, which will enhance nurse retention.

\section{ETHICAL CONSIDERATIONS}

Permission was obtained from the Head of Human Resources of the Gauteng Provincial Department of Health, and chief executive officers heading the participating hospitals in Gauteng. In the private sector, directors of nursing of the private hospital groups, as well as regional nurse managers, gave permission. The nurse managers, who participated voluntarily, gave informed consent. Anonymity was guaranteed because no nurse manager's name and no health care institution's name would be mentioned in any report. Confidentiality was maintained because no information would be linked to any specific interviewed nurse manager. Only the researchers and data analyst had access to the audiotapes and the transcribed data, which were kept secure. Subsequent to the acceptance of the research report, the audiotapes and verbatim transcriptions would be destroyed, and participants could request a research report, which would be supplied.

\section{TRUSTWORTHINESS}

The truth value of the data was measured against the four constructs which are described by Lincoln and Guba (in Marshall \& Rossman 1995:143), and comprise credibility, transferability, dependability and conformability, and this is summarised in Table 4.

\section{DISCUSSION}

This study found that general factors such as working conditions, relationships in the work environment and the image of nursing influence nurse retention. Organisational factors such as a lack of safety and resources, policies and the culture within an organisation also contribute to retention or

TABLE 4

Measures for enhancing trustworthiness

\begin{tabular}{|c|c|c|}
\hline Construct & What is measured & Steps taken to ensure constructive measurement \\
\hline Credibility & $\begin{array}{l}\text { True representation of occurrences as experienced } \\
\text { by respondents }\end{array}$ & $\begin{array}{ll}\text { - } & \text { Literature control } \\
\text { - } & \text { Member checking } \\
\text { - } & \text { External control by two experienced researchers }\end{array}$ \\
\hline Transferability & $\begin{array}{l}\text { Applicability of findings to another context or with } \\
\text { other respondents }\end{array}$ & $\begin{array}{ll}\text { - } & \text { Purposive sampling } \\
\text { - } & \text { Thick description of data } \\
& \text { Recommendations for further research }\end{array}$ \\
\hline Dependability & $\begin{array}{l}\text { Consistency and extent to which outcomes of the } \\
\text { study can be replicated }\end{array}$ & $\begin{array}{l}\text { - External control: Two supervisors were involved throughout the process } \\
\text { - }\end{array}$ \\
\hline Confirmability & Neutrality and the objectivity of data & $\begin{array}{l}\text { - Checking and re-checking data obtained from interviewees; comparing data with literature reports } \\
\text { - } \quad \text { Researcher's familiarity with qualitative methods }\end{array}$ \\
\hline
\end{tabular}


turnover. Nurse managers play an important role in enhancing nurse retention but lack power, managerial and leadership skills to manage the multigenerational workforce. Nurse managers require knowledge to deal with situations that influence nurses contemplating leaving the organisation. In order to be retention managers, they need to acquire skills through training and development, as well as through a suitable leadership style. Changing certain contributory factors and creating a work environment with characteristics that promote quality patient care, safety and autonomy, will add to the attraction and retention of professional nurses.

The multigenerational workforce brings challenges to the workplace because of their generational specific values, norms and behaviours. Nurse managers have to keep this in mind when making managerial decisions. It is essential that nurse managers become conversant with different generational characteristics, especially those of generation $X$ and $Y$, to be able to lead and manage them effectively, so that they do not leave their organisations. In today's climate of critical nurse shortages and increasing workloads, it becomes crucial that nurse managers adopt management and leadership styles that serve the nurses in order that they may better serve their patients and clients.

Vogt et al. (1983), in their Cork-top Bottleneck Theory of Nurse Retention, identify the levels of needs (lack of resources, unsafe working areas), but go further by demonstrating the areas where these needs are constricted (lack of promotion opportunities) Identifying and addressing the areas of constriction will enable health care managers and authorities to enhance the retention of nurses in their employ. Lewin's (1952) Force Field Analysis theory offers a valuable change management strategy and emphasises the driving and restraining forces associated with any change. Before deciding whether to leave or stay in an organisation, a nurse will weigh up certain driving and restraining forces: Driving forces will be the positive things which are favourable to the nurse, while restraining forces are those elements that the nurse dislikes and considers negative. By examining these forces, authorities will be able to pre-empt the possibility of a nursing exodus and implement strategies to enhance retention. This requires a planned process, whereby the old status quo is removed, change is implemented and the new strategy entrenched. The process entails unfreezing the current situation, implementing change and refreezing the new status quo. In order to achieve the desired goal, managers, supported by authorities and in communication with professional nurses in their charge, can effect the necessary change by ensuring that driving forces outweigh restraining forces. By strengthening the driving forces and weakening restraining forces, change for the better can be accomplished. Ways in which restraining forces could be limited include improving the security at hospitals in the parking areas, and lighting passages properly, ensuring that there are sufficient resources and that equipment remains in good working order, and paying nurses competitive salaries and decent rates for working overtime. The driving forces which can be strengthened include establishing and maintaining effective communication lines amongst nurses, but also between nurses and all other categories of health workers, with patients and their visitors. Clearly stated policy guidelines will help to reduce uncertainties in the workplace.

Nursing shortages are sure to continue, especially with the impending exit of retiring baby boomers. This makes the practice of retaining nurses essential. Health care authorities and managers have a responsibility to improve work environments and conditions, so that professional nurses will want to stay.

\section{LIMITATIONS OF THE STUDY}

This study used a qualitative approach, conducted in Gauteng, which is largely an urban province. A purposive sample of nurse managers employed in public and private hospitals was selected, which might limit the generalisability of the findings to other hospitals in other provinces and to hospitals in rural areas.

\section{RECOMMENDATIONS}

Based on the findings of this study it is recommended that South African health care authorities and employers address:

- The concerns of nurse managers regarding the working conditions, workload and conditions of service of nurses.

- Issues of safety in the work environment by improving security services and ensuring that sufficient resources and equipment are available.

- The powerlessness of nurse managers by involving them in strategic planning regarding the retention of their workforce.

- Shortcomings in managerial and leadership skills of the nurse managers through relevant workshops, short courses and human resource development programmes.

Based on the findings of this study it is recommended that research be conducted in the following areas:

- Re-employment of retired nurses as a potential solution to the shortage of nurses.

- Job satisfaction of the multigenerational nursing workforce.

- Inter-generational conflict in the workplace and nurse retention.

\section{CONCLUSION}

This study found that factors pertaining to individual nurses, the organisation and nurse managers could influence the retention of professional nurses. Poor working conditions, long and inconvenient working hours, uncompetitive salaries and limited professional development opportunities for nurses need to be addressed. Enhancing the image of nursing and creating a harmonious workplace where a multigenerational nursing workforce feels valued will improve retention. Organisational factors that will enhance retention have to be acknowledged. Managers perceive the hospitals where they work as unsafe with nurses being potential victims of violence and criminal acts and where patient safety is threatened by an increase in medicolegal risks as a result of a lack of resources and staff shortages. The organisational culture of each institution is instrumental in deteriorating or enhancing professional nurses' retention rates. Nurses need to be empowered to make decisions without being doubted, and senior nurses need to empower their subordinates. This might influence retention positively. Shortcomings in communication, managerial and leadership skills were recognised. Nurse managers need to implement change within a multigenerational environment, but require specific skills and knowledge to do so effectively.

\section{ACKNOWLEDGEMENTS}

We thank all the nurse managers who participated in the study.

\section{REFERENCES}

Aiken, L.H., Smith, H.L. \& Clarke, E.T., 1994, 'Lower medicare mortality among a set of hospitals known for good nursing care', Medical Care 32(8), 771-785.

American Nurses' Association, 2001, Code of ethics for nurses with interpretive statements, American Nurses' Association, Washington.

Barney, S.M., 2002, 'The nursing shortage: why is it happening?' Journal of Health Management 47(3), 153-155.

Bethune, G., Sherrod, D. \& Youngblood, L., 2005, 'Tips to retain a happy, healthy staff', Nursing Management 36(4), 24-30.

Bliss-Holtz, J., Winter, N. \& Scherer, E.M., 2004, 'An invitation to magnet accreditation', Nursing Management 35(9), 36-42.

Booyens, S.W. (ed), 1998, Dimensions of nursing management, 2nd edn., Juta, Kenwyn.

Butler, A.S., 2000, 'Best place to work', Executive Excellence $17(11), 4-5$.

Cameron, S. \& Armstrong-Stassen, M., 2005, 'Retention of community nurses: strategies for success. Innovations in retention of nurses', viewed 03 May 2006, from http://stti. confex.com/stti/inrc16/techprogram/paper_21876.htm 
Cook, A., Hiroz, J. \& Mildow B., 2006, Strategies and outcomes associated with magnet hospitals, Nursing Health Services Research Unit, Toronto.

Creswell, J.W., 2003, Qualitative, quantitative and mixed methods approaches, 2nd edn., Sage, Thousand Oaks.

De Vos, A.S., Strydom, H., Fouché, C.B. \& Delport, C.S.L., 2005, Research at grass roots for the social sciences and human service professions, 3rd edn., Van Schaik, Pretoria.

Donnelly, M.C., 2003, 'Why leadership is important to nursing', in N.H. Holmes (ed.), Five keys to successful nursing management, n.p., Lippincott Williams \& Wilkins, Philadelphia.

Duchscher, J.E. \& Cowin, L., 2004, 'Multigenerational nurses in the workplace', Journal of Nursing Administration 34(11), 493501.

Ehlers, V.J., 2003, 'Professional nurses' requests to remove their names from the South African Nursing Council's register. Part 1: Introduction and literature review', Health $S A$ Gesondheid 8(2), 63-69.

El-Jardali, F., Jamal, D., Abdallah, A. \& Kassak, K., 2007, 'Human resources for health planning and management in the Eastern Mediterranean region: Facts, gaps and forward thinking for research and policy', Human Resources for Health 5(9), 1-12.

Fitzpatrick, M.A., 2003, 'Getting your team together', in N.H. Holmes (ed.), Five keys to successful nursing management, n.p., Lippincott Williams \& Wilkins, Philadelphia.

Fletcher, C.E., 2001, 'Hospital RN's job satisfaction and dissatisfactions', Journal of Nursing Administration 31(6), 324 331.

Force, M.V., 2005, 'The relationship between effective nurse managers and nursing retention', Journal of Nursing Administration 35(7/8), 336-341.

Furnham, A., 1997, The psychology of behaviour at work: The motivation in the organization, Psychology Press, Hove.

Gopwani, J., 2004, 'Boomer bust: New opportunities for generation $\mathrm{X}$ and $\mathrm{Y}^{\prime}$, Business news, viewed 01 July 2005, from http://www.freep.com/money/business/ genxy27e20041227.htm

Gurney, G.A., 1990, Determinants of intent to leave among nurses with doctoral degrees, UMI Dissertation Services, Chicago.

Hall, E.J., 2004, 'Nursing attrition and the work environment in South African health facilities', Curationis 27(4), 28-36.

Hammill, G., 2005, 'Mixing and managing four generations of employees', FDU Magazine, viewed 27 August 2005, from http: / / www.fdu.edu/newspubs / magazine / OSWS / generations.htm

Hart, S.M., 2006, 'Generational diversity: Impact on recruitment and retention of nurses', Journal of Nursing Administration 36(1), 10-12.

Health Systems Trust (HST), 2008, 'Percentage of professional nurse posts vacant', viewed 14 April 2008, from www.hst. org.za/healthstats/140/data

Jooste, K (ed.), 2003a, Leadership in health services management, Juta Academic, Lansdowne.

Jooste, K., 2003b, 'Essential Managerial attributes of the nowadays nursing service manager in the South African context', Curationis 26(2), 19-29.

Kaestner, R., 2005, 'An overview of public policy and the nursing shortage', Journal of Nursing Administration 35(1), 8-9.

Lewin, K., 1952, Field theory in social science: Selected theoretical papers, Tavistock, London.

Marshall, C. \& Rossman, G.B., 1995, Designing qualitative research, 2nd edn., Sage, Thousand Oaks.

Maxwell, M., 2004, 'Recruitment realities: Building a HR/ nursing partnership', Nursing Economics 22(2), 86-87.

Moore, D.P., 2002, 'Workplace generational differences noteworthy', Business Major 20 (May), 1.

Naude, M. \& McCabe, R., 2005, 'Increasing retention of nursing staff at hospitals: Aspects of management and leadership', WISER Working Paper no 43, viewed 12 March 2007, from http:/ / www.cbs.curtain.edu.au/wiser
Neuhauser, P.C., 2002, 'Building a high retention culture in healthcare', Journal of Nursing Administration 32(9), 470-477.

Oosthuizen, M.J., 2005, 'An analysis of the factors contributing to the emigration of South African nurses', unpublished D Litt et Phil thesis, Department of Health Studies, University of South Africa.

Pullan, S.E. \& Lorbergs, K.A., 2001, 'Recruitment and retention. A successful model in forensic psychiatric nursing', Journal of Psychosocial Nursing 39(9), 18-25.

Rhule, K.J., 2004., 'The effects of the managers' behaviour on the retention of high potential employees from different generations', unpublished D Ed Thesis, Duquesne University.

Runy, LA., 2006, 'Cultural transformation', Hospital and Health Networks 18(April), 1-4.

Rosebrough, C., 1999, 'Retaining "Me Generation" nurses: Management strikes back', Managerial Thought Shots 1(3), $1-3$.

Schwering, R.E., 2003, 'Focusing leadership through force field analysis: New variations on a venerable planning tool', Leadership and Organization Development Journal 24(7), 361370.

Sellgren, S., Ekvall, G. \& Tomson, G., 2006, 'Leadership styles in nursing management: Preferred and perceived', Journal of Nursing Management 14(5), 348-355.

Shaffer, F.A., 2003, 'Stepping outside of yesterday's thinking: Preparing nurse managers for a new world order', Nurse Leader 1(4), 33-37.

Sherman, R., 2006, 'Leading a multigenerational workforce: Issues, challenges and strategies', The Online Journal of Issues in Nursing 11(2), manuscript 2, viewed 20 May 2006, from http://www.nursingworld.org/ojin/topic30/tpc30_2htm

South African Nursing Council (SANC), 2005, 'Output of 4yr program from South African nurse training institutions', viewed 12 April 2006, from: http/ /:www.sanc.co.za

Statistics South Africa, 2006, 'Population of South Africa, 1996-2006', viewed 02 November 2006, from http://www. sanc.co.za

Strachota, E., Normandin, P., O'Brien, N., Clary, M. \& Krukow, B., 2003, 'Reasons registered nurses leave or change employment status', Journal of Nursing Administration 33(2), 111-117.

Stuenkel, D., Cohen, J. \& De La Cuesta, K., 2005, 'The multigenerational nursing workforce: Essential differenes in preceptors of work environment', Journal of Nursing Administration 35(6), 283-285.

Sullivan, E.J. \& Decker, P.J.C., 2001, Effective leadership and management in nursing, 6th edn., Jones \& Bartlett, Upper Saddle River, NJ.

Tappen, R.M., 2001, Nursing leadership and management: Concepts and practice, 4th edn., FA Davis, Philadelphia.

Tappen, R.M., Weiss, S.A. \& Whitehead, D.K., 2004, Essentials of nursing leadership and management, F.A. Davis, Philadelphia.

Upenieks, V.V., 2003, 'Assessing differences in job satisfaction of nurses in magnet and non-magnet hospitals', Journal of Nursing Administration 32(11), 564-576.

Vogt, J.F., Cox, J.L., Velthouse, B.A. \& Thames, B.H., 1983, Retaining professional nurses: A planned process, Mosby, London.

Williams, K.A., Stotts, R.C., Jacob, S.R., Stegbauer, C., Roussel, P. \& Carter, D. 2006, 'Inactive nurses: A source for alleviating the nursing shortage?' Journal of Nursing Administration 36(4), 205-210.

Wilson, A.A., 2005, 'Impact of management development on nurse retention', Nursing Administration Quarterly 29(2), 137145.

Xaba, J. \& Phillips, G., 2001, 'Understanding nurse emigration: Final report. Pretoria: Trade Union Research Project (TURP)', Denosa, Pretoria. 